\title{
Bringing information literacy into the academic curriculum
}

\author{
By Hannelore B. Rader \\ Director, University Library \\ Cleveland State University
}

\section{A comprehensive information literacy program established at Cleveland State.}

leveland State University is now celebrating its 25th anniversary as an urban university. The University has an enrollment of 18,500 students, 539 faculty, and offers a wide range of undergraduate courses, 25 master and six Ph.D. programs, and Master of Laws and Juris Doctor degrees. Over $95 \%$ of the students are residents of Cuyahoga County and six neighboring counties. $53 \%$ of the students are full-time and $47 \%$ are parttime. Undergraduates are, on average, 25 years old; graduate students average 33 ; and law students average 30 . Over $85 \%$ of the students are employed locally, while $60 \%$ are employed full-time.

The University Library has recently implemented an integrated library automation system based on NOTIS Systems, Inc., and features an electronic reference center with a number of electronic databases on CD-ROM and diverse online searching capabilities. Cleveland State is well on its way to becoming an electronic library in tandem with its collection of more than one million volumes, microforms and audiovisual materials.

A full-scale library instruction program features all levels of instruction and involves most librarians. At the same time, most librarians are also partners with faculty in the development of the collections through an active librarian-faculty liaison program.

Librarians have a special status on campus as the only non-faculty group to have an elected representative on the Faculty Senate. The library director serves as ex-officio on the Senate, the Graduate Council and the University Curriculum Committee.

For more than five years, various University Curriculum Committees attempted to revise the University's basic curriculum. Each year, the University Curriculum Committee (UCC) presented a plan for a revised basic university curriculum to the Faculty Senate, which was rejected by that group through 1988.

During the 1988/89 academic year, the UCC was charged by the Faculty Senate to work with the University Committee to develop yet another major revision of the basic university curricular requirements, to be completed by all students in order to graduate from Cleveland State University. The UCC, composed of ten elected faculty representing the Business, Engineering, Urban Affairs, Law, Arts \& Sciences Colleges, as well as the library director and a representative from the Provost's Office, divided its work into three phases.

Phase one proposed a structural pattern for the revised curriculum and flexible guidelines for negotiation with the faculty in departments and in the Senate. This was approved in June 1989. During the 1989/90 academic year, phase two focused on 
negotiations with major departmental stake holders. This phase featured special working groups for each fundamental area of knowledge, each chaired by a member of the UCC. The library director chaired the working group on "Non-Western Culture and Civilization," while the library coordinator of bibliographic instruction was a member of the Working Group on the Writing Requirement. Phase three involved the completion of the revision of the basic university curricular requirements. Final approval by the Faculty Senate was obtained June 13, 1990.

The revised curriculum, to be implemented in Winter 1992, features 63 credit hours in fundamental areas of skills, knowledge and disciplines, as well as six credit hours of designated writing courses and eight credit hours of courses on the African-American experience.

Throughout the revision process, the library director emphasized the importance of including an information literacy component into the revised basic curriculum. The rationale was that information-literate students are able to understand the importance of information in our society, to articulate and focus their information needs, to understand the structure and form of information, to recognize the points of access to information, to develop strategies for information gathering, to evaluate and analyze information content, to synthesize, manage, and report their results, and to evaluate their search process.

The UCC had no problem with including such a component into the revised basic curriculum. Also, the librarians, together with the library director, continued to brief members of the Faculty Senate and other faculty on this important issue. When the final UCC report was debated at the Senate, there was no objection to the information literacy component, which was included as follows:

\section{"Information Literacy}

The Cleveland State University Library has made the commitment to initiate an Information Literacy program as an expansion of the present bibliographic instruction programs in which librarians, in cooperation with faculty, have been instructing students in using library materials. Through the information literacy program, students will be able to locate, evaluate, and use information more effectively to satisfy their information requirements. Librarians will work with all faculty members to include information literacy modules into appropriate courses, and to monitor students' progress in becoming information-literate."

In addition, the report includes sample course nomination forms that must be filled out by faculty when proposing courses to fit into the revised basic curriculum. Each of these forms includes the question:

"How does this course deal with information and information literacy in the field?"

During the two years of the curriculum revision process, the librarians, under the leadership of the coordinator of bibliographic instruction, established principles, goals and objectives for a comprehensive information literacy program at CSU. Information literacy was also a focus in the last two annual reports and in all newsletters to the faculty.

Thus, the framework has been put in place at Cleveland State University for implementing a comprehensive information literacy program at a large, urban university. The librarians are now developing a methodology for teaching the evaluation of information and information resources and criteria for measuring the outcomes of this program.

\section{8-89 academic library statistics available from ACRL}

ACRL University Library Statistics 1988-89, a review of the year's activities of 114 university libraries, is now available from the Association of College and Research Libraries (ACRL).

The participating libraries reported holdings of $92,635,350$ volumes and expenditures of $\$ 158,308,733$ for the purchase of library materials. Nearly 11,581 people are employed by these libraries (2,984 professional, 5,468 non-professional and 3,102 FTE student workers).

The data is published every two years by ACRL and is compiled from information provided by cooperating university libraries in the United States and Canada. Data is provided in the areas of collections, serials, expenditures, enrollment, per- sonnel and interlibrary loan. Institution rankings are included. The publication is intended for university and library administrators to compare their own management and collection data with those of comparably sized institutions around the country.

The book was compiled by Denise Bedford, a member of ACRL's Academic Library Statistics Committee. Purchasers may request a free copy of the data in machine-readable form.

The 79-page paperback, printed on acid-free paper (ISBN 0-8389-7446-5), sells for $\$ 49.95$ ( $\$ 29.95$ to ACRL members). It may be ordered from ALA Publishing Services, Order Department, 50 E. Huron St., Chicago, IL 60611-2795; (800) 545-2433; fax, (312) 440-9370. 


\section{The Ultimate Acquisition Management Tool}
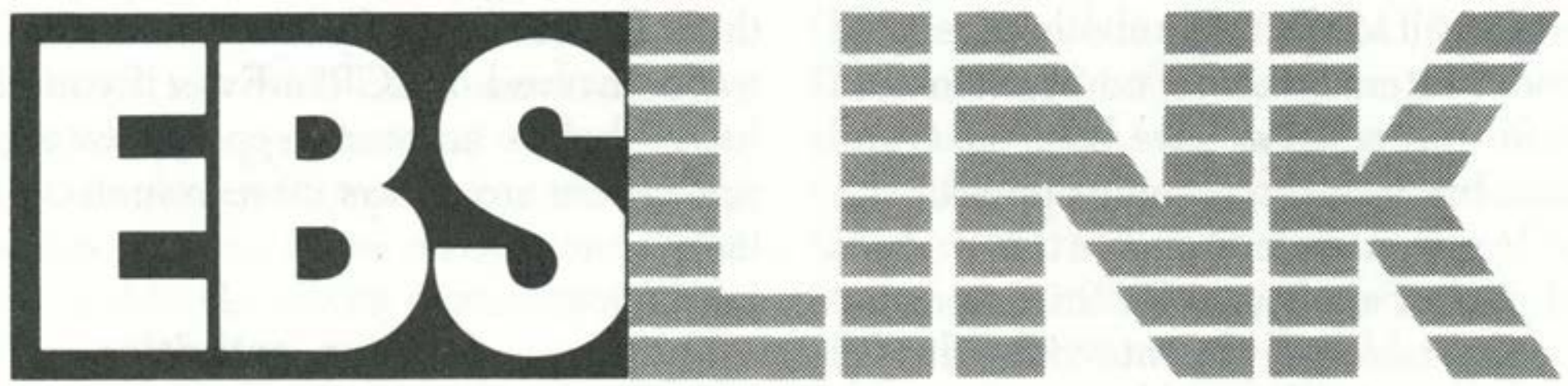

EBS announces a software package designed to serve the professional librarian's needs-NOT THE NEEDS OF YOUR VENDOR. EBS LINK isn't just an ordering device or a list of your vendor's inventory; EBS LINK is a management tool that will HELP YOU THROUGHOUT the acquisitions process.

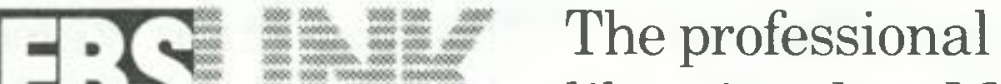

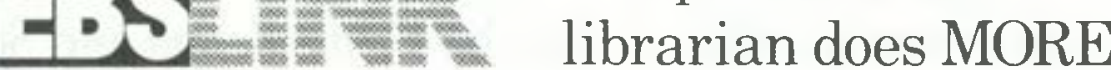

than order books. We realize that and we created EBS LINK to be an ACQUISITIONS MANAGEMENT TOOL. It keeps track of all your budgets, retrieves information the way you should have it, and helps you to be a more efficient librarian.

Every library can use an extra arm or two in its acquisitions department. EBS LINK can help you make EBS your extra arm.

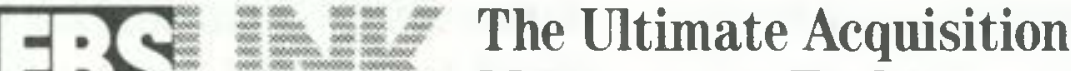

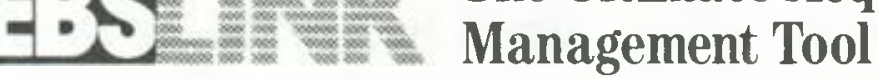

For information about obtaining EBS LINK at no charge, call:

\section{1-800-899-0290}

or write:

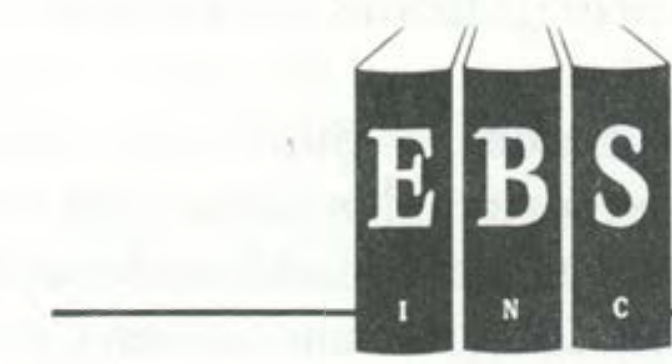

